\title{
Review on the Positive and Negative Impact of Covid-19 Pandemic on Environment and Society
}

\author{
Soad Najmaldin Mohialdin \\ Chemistry Department, College of Education, \\ Salahaddin University, Erbil, Iraq
}

\begin{abstract}
This review search aims to show the positive and negative impact of COVID-19 on the all aspects of life such as environment, education, economy, politics, social life, and social media, and most importantly global human health and health services. particularly in the most affected countries such as China, USA, Canada, Italy, Spain, Germany, UK, Brazil, Mexico, India, and Iraq. In terms of the environment our search shows that there is a positive impact associated between measures and improvement in air quality, reduction of fossil fuel traffic pollutes, reduction in greenhouse gases (GHG) generation, clean beaches, and environmental noise reduction due to air traffic suspension. The negative impact was associated with aspects such as the reduction in recycling and the increase in waste, which was endangering the contamination of natural resources (water and land), in addition to air. Other negative impacts on reduction global economic activity. In terms of education, COVID-19 had a big effect in changing the education system from classroom to electronic learning. The COVID19 pandemic has had far-reaching economic consequences beyond the spread of the disease itself and efforts to quarantine it. As this virus has spread around the globe, concerns have shifted from supply-side manufacturing issues to decreased business in the services sector. The pandemic caused the largest global recession in history, with more than a third of the global population at the time being placed on lockdown. ((Anon., April-2020) Health-wise it was the reason for the reduction of the world population due to the high mortality and death rate. This is expected to be carried on for unpredicted months perhaps a year until the right vaccine is in reach of every person in the world.
\end{abstract}

Keywords: (GHG), COVID-19, vaccine, Pandemic, Environmental impact, Global

\section{Introduction}

The COVID-19 pandemic has led to a dramatic loss of human life worldwide and presents an unprecedented challenge to public health, food systems and the world of work. The economic and social disruption caused by the pandemic is devastating: tens of millions of people are at risk of falling into extreme poverty, while the number of undernourished people, currently estimated at nearly 690 million, could increase by up to 132 million by the end of the year of 2020. In this study we focusing on the 
positive and negative impact of COVID-19 pandemic in several global issues which has been affected with this pandemic, such as environment, education, connectedness, peace, Enovation and economy. (impact-of-covid- 19-on-people.., 2020)

COVID 19's impact on the environment has been mixed. Although the pandemic resulted in improved environmental conditions, there have been other negative effects, some of which are obvious, others less.

In brief, the positive effects have been reduced GHG (greenhouse gas) emissions, improved water quality, reduced noise pollution, improved air quality and in some cases, wildlife restoration. Negative effects have been increased medical waste, haphazard disposal of PPE, increased municipal waste and reduced recycling efforts.

The unprecedented current situation caused by Covid-19 has disrupted most professions across the globe with accounting and auditing being no exception. Mandatory lockdown measures were imposed by governments to control the spread of the virus, with individuals having to work from home where possible. For auditors, this means they can no longer travel to audited entity premises, nor even to their own offices and that their audits will have to be completed remotely.

If there is a positive side to this significant challenge for auditors, it is that the audit profession was already on a journey to becoming more digital, and the investment in digital capability has allowed many firms and practitioners to adapt to the new circumstances relatively more quick than other industries.

COVID-19 has had undeniable and horrific consequences on people's lives and the economy. With sickness, death, and unemployment rates soaring almost everywhere on our planet, it is easy to despair.

The global impact of Coronavirus is immense as educational institutes all over the world are closed. Covid-19, has thrown education all over the world in a loop. Schools are shut, and students are stranded at home, with extremely limited contact with friends and virtually no physical activity, thanks to the Covid-19 pandemic raging across the world. IB, A-Levels, ICSE, CBSE knew and recognized boards have postponed or cancelled examinations. Likewise, top colleges like MIT, Harvard, Princeton have closed. (seven-positive- outcomes-of-covid-19, 2020)

Closer home, institutions like IITs and IIMs have all closed their campuses and moved classes online. Even standardized tests like GCSE, A levels, GNVQ, SATs, remain suspended and the future of many students hangs in balance! There is panic all around and educators and students alike are confused as to the next steps and continuity concerning educational objectives. (how-is-the-covid-19-pandemic-affectingeducation-all- over-the-world, 2020-04-07)

Corona virus pandemic has wide-ranging and severe impacts upon financial markets, including stock, bond and commodity (including crude oil and gold) markets. Major 
events included the Russia-Saudi Arabia oil price war that resulted in a collapse of crude oil prices and a stock market crash in March 2020.

The United Nations Development Programme expects a US $\$ 220$ billion reduction in revenue in developing countries, and expects COVID-19's economic impact to last for months or even years. (Noticias, 30 March 2020), (A b Palumbo D. (., 2020)

Positive impacts of COVID-19:

Despite the COVID-19 undeniable and horrific consequences on people's lives and the economy.

With sickness, death and unemployment rates soaring almost everywhere on our planet, it is easy to despair. It had some positive impacts on the environment and society. Seven positive outcomes have been summarised below:

\section{Environment}

The first positive aspect of COVID-19 is the effect on the environment. Carbon emissions are down globally and with manufacturing and air travel grinding to a halt, the planet has had a chance to revitalise. (covid-19-the-impact-of-coronavirus-onthe-environment., 20200326)

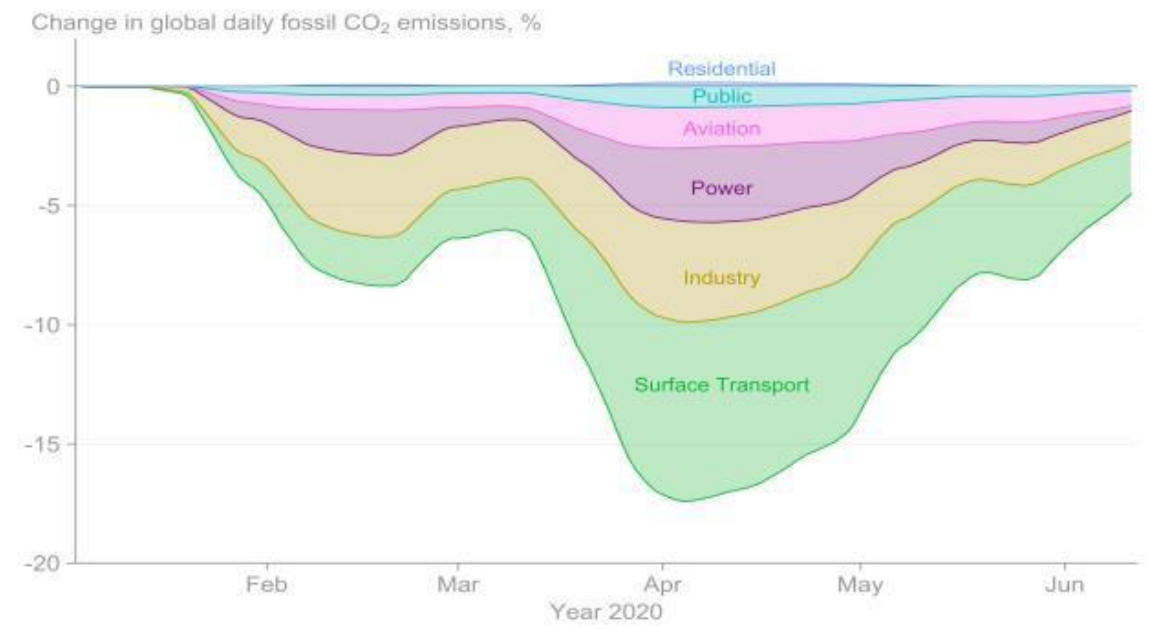

China recorded an 85 per cent increase in days with good air quality in 337 cities between January and March. With tourists gone from Italy, the long-polluted canals of Venice now appear clear as fish and other wildlife start returning. Elsewhere, wildlife is also reappearing in other major cities and the biodiversity is slowly starting to return in various parts of the world.

NASA and ESA have been monitoring how the nitrogen dioxide gases dropped significantly during the initial Chinese phase of the COVID-19 pandemic. The 
economic slowdown from the virus drastically dropped pollution levels, especially in cities like Wuhan, China by $25-40 \%$. NASA uses an ozone monitoring instrument (OMI) to analyse and observe the ozone layer and pollutants such as NO2, aerosols and others. This instrument (un.org/en/un-coronavirus-communications-team). (coronavirus- communications-team/fury-virus-illustrates-folly-war) helped NASA to process and interpret the data coming in due to the lock-downs worldwide this was reported in the image below: (un-coronavirus- communications-team, 2020) ., (23 September 2020.; Times, "Pandemic knocks a tenth off incomes of workers around the world".)

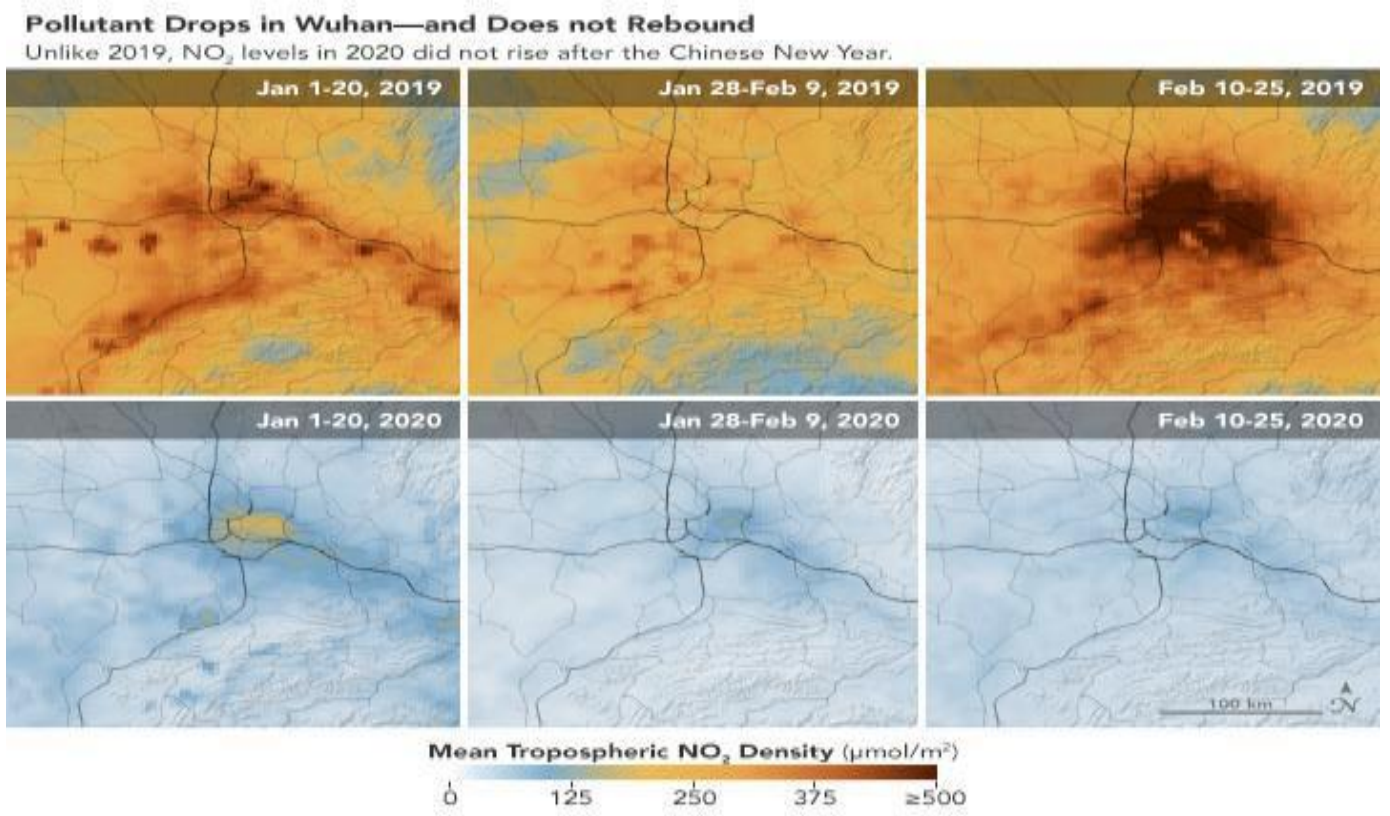

Images from the NASA Earth Observatory show a stark drop in pollution in Wuhan, when comparing NO2 levels in early 2019 (top) and early 2020 (bottom). (Earth Observatory"., 2020)

\section{Peace}

The coronavirus is also raising hopes of fewer battles and less conflict, resulting in increased levels of peace. The United Nations called to end all wars in the face of COVID-19 as the world confronts a common enemy: "It's time to put armed conflict on lockdown," stated Secretary-General António Guterres.

So many businesses have had to reinvent themselves with a new 'business as unusual' philosophy. According to the ABC, a ceasefire, was declared by the Saudis fighting Houthi rebels in Yemen. Although there are many places in the Middle East where war persists, a stronger lockdown could lead to less violence in these countries too. 
(Times, Pandemic knocks a tenth off incomes of workers around the world, 23 September 2020.), (abc.net.au, 2020-04-10)

All countries in the world showed their humanity to their own people. They become introspective and taking quick decisive and positive action. Everyone agreed the importance of quarantine and the new word that sprout out like enhance 14-day quarantine, lock down, social distancing, boarder closing from all countries. The leaders of the world scampered in unity on how to combat this disease and have never been cooperative in sharing best practices on how to prevent o stop the spread of this virus. There is a complete change in dealing with fellow human. We tend to protect ourselves from being too near for the sake of oneself and everyone.

The new order is to stay at home, showed to be a positive sign, maybe we need to go back to the basics of life. Family! We need to have more time for our loved ones. Bonding this time is enforced by the circumstances, or is it. It could be a message from each of one to prioritize our priorities. They are our family, our health and our values on life. It is a wakeup call for the religious or spiritual or believer or whatever to meditate about life and how we suddenly see the changes in pattern at looking at things. (A b Palumbo D. (., 2020)

\section{Connectedness}

A third positive outcome is a revitalizing sense of community and social cohesion. Self-isolation challenges us as social animals who desire relationships, contact and interaction with other humans.

However, people all around the world are finding new ways to address the need for interconnectedness. In Italy, one of the worst-hit countries, people are joining their instruments and voices to create music from their balconies. People are leading street dance parties while maintaining social distancing. People are using social media platforms to connect, such as the Facebook group The Kindness Pandemic, with hundreds of daily posts. There is a huge wave of formal and informal volunteering where people use their skills and abilities to help. (newyorker.com/culture/videodept/the-, 2020)

\section{Innovation}

COVID-19 is a major market disruptor that has led to unprecedent levels of innovation. Due to the lockdown, so many businesses have had to reinvent themselves with a new 'business as unusual' philosophy. This includes cafes turning into takeaway venues (some of which also now sell milk or face masks) and gin distilleries now making hand sanitisers. Many businesses have had to undergo rapid digitalisation and offer their services online. Some could use this wave of innovation to reimagine their business model and change or grow their market. 


\section{Corporate Responsibility}

Coronavirus is driving a new wave of corporate social responsibility (CSR). The global pandemic has become a litmus test for how seriously companies are taking their CSR and their work with key stakeholders: the community, employees, consumers and the environment. Home-schooling is becoming the new way of learning, exposing many parents to what their children know and do. Companies are donating money, food and medical equipment to support people affected by the coronavirus. Others are giving to healthcare workers, including free coffee at McDonald's Australia and millions of masks from Johnson \& Johnson. Many are supporting their customers, from supermarkets, introducing an exclusive shopping hour for seniors and people with disabilities to Optus giving free mobile data so its subscribers can continue to connect.

(lighthouse.mq.edu.au, april-2020), (jnj.com, 2020), (woolworths.com.au, 2020), (optus.com.au, 2020)

There must be a global human-centred response which is grounded in solidarity. International Labour Standards (ILS) contain guidance for ensuring decent work that is applicable even in the unparalleled

context of the COVID 19 crisis. In particular, the Employment and Decent Work for Peace and Resilience Recommendation, emphasizes that crisis responses need to "ensure respect for all human rights and the rule of law, including respect for fundamental principles and rights at work and for international labour standards". The standards dealing with safety and health at work, social security, employment, non- discrimination, working arrangements and the protection of specific categories of workers provide guidance on the design of rapid responses that can facilitate a stronger recovery from the crisis. A coordinated global effort is required to support countries that currently do not have sufficient revenues space to finance social policy, in particular universal social protection systems. Debt sustainability should be prioritized in this endeavour. (R205, 2017)

\section{Education}

The sixth positive outcome is massive transformation in education. True, most of it was not by choice.

With schools closing down all around the world, many teachers are digitalising the classroom, offering online education, educational games and tasks and self-led learning.

Silver linings amid the suffering: Professor Debbie Haski-Leventhal believes a new found sense of gratitude for freedoms we take for granted and a global trend in thanking health workers who are at the frontline are among the positives to come out of the crisis. We are globally involved in one of the largest-scale experiments in 
changing education at all levels. Home-schooling is becoming the new way of learning, exposing many parents to what their children know and do.

Similarly, universities are leading remote learning, and use state-of-the-art solutions to keep students engaged. Some universities are using augmented and virtual reality, to provide near real-life experiences for galvanising students' curiosity, engagement and commitment and for preparing students for the workplace. (newyorker.com/new, 2020), (timeshighereducation.com, 2020), (edsurge.com/news, 2020-03-18)

Four positive changes in education due to Covid-19

Any change that is so disruptive is also likely to bring with it some new opportunities that will transform the higher education system worldwide and especially in a country like India which is planning to bring about a planned reform in this sector. Some of the key areas of opportunity are the following:

\section{Rise in Blended Learning}

Universities and colleges will shift to a model of blended learning where both face-toface deliveries along with an online model will become a norm. This will require all teachers to become more technology savvy and go through some training to bring themselves to the level that would be required.

\section{Learning management systems to be the new standard}

A great opportunity will open up for those companies that have been developing and strengthening learning management systems for use by universities and colleges. This has the potential to grow at a very fast pace but will have to be priced appropriately for use by all institutions.

\section{Improvement in learning material}

There is a great opportunity for universities and colleges to start improving the quality of the learning material that is used in the teaching and learning process.

Since blended learning will be the new format of learning there will be a push to find new ways to design and deliver quality content especially due to the fact that the use of learning management systems will bring about more openness and transparency in academics.

\section{Rise in collaborative work}

The teaching community to a large extent has been very insulated and more so in a country like India. There is a new opportunity where collaborative teaching and learning can take on new forms and can even be monetized. Finally, it is expected that there will be a massive rise in teleconferencing opportunities which can also have a negative impact on the travel. 
A large number of academic meetings, seminars and conferences will move online and there is a possibility that some new form of an online conferencing platform will emerge as a business model.

After all this, there is one certainty that we can envisage and that is going to change how higher education will operate globally. There no one country just going through a reform in the higher education sector, but now it will go through a major transformation in general. (msn.com/en-in/news/world, 2020), (indiatoday.in/education-today., 2020), (Kamlesh Misra, 2020)

\section{Covid-19: Education system's big shift from classrooms to computers}

The biggest change that the education system globally has seen this year is the massive shift to e- learning or digital classrooms. The first few weeks after outbreak of virus, have observed heightened awareness of the Coronavirus outbreak in the nation. In an earnest effort to contain this virus, several measures are being implemented by the government. To reduce large gatherings, locking down the country is the major step that the government has taken towards safeguarding the citizens of the nation.

While most of the corporate industry is functioning from home; schools, colleges and other institutions have ordered temporary shut down too. As the virus spreads across the globe, let us understand what it means to the education of the students, who are now under the 'house arrest' (Indiatoday, 2020).

\section{Number of schools shut due to Covid-19}

Earlier UNESCO had announced that 22 countries had closed schools, affecting over 290 million children, while nine other countries had implemented localized closures.

Considering millions of school-going students, and their health and safety, it's time to harness digital platforms judiciously to ensure that their learning does not stop.

UNESCO too suggested that digital learning platforms can help students' access to quality education remotely during times like these.

\section{Shift to E-learning}

The crisis is always paired with opportunities. And it's time to appreciate the full potential of technology for learning. In the wake of this medical emergency and keeping the students' safety in mind along with their academic concern, different stakeholders in the education space have been endorsing online learning so that the learning only grow and do not recede.

Majority of private schools and other educational institutions have initiated mandatory virtual classes on a daily basis, and thus, teachers are unfailingly sharing their lessons over skype call, zoom call or any other virtual class options to keep the learning on. 
Wherever and whenever required, the training is provided to students and teachers through videos to use technology to facilitate virtual classes. Some education institutes are also providing pre-recorded videos of lessons to students where teachers explain the topics extensively. With this uncertainty on the horizon, EdTech players in India have also decided to take it upon themselves to help students stay at home without compromising on their lessons. These companies are creating a breakthrough, offering free access to their courses during a time that typically flags off the exam season. At the same time, the move has been met with an overwhelming response from the students.

\section{Benefits of E-learning}

The digital learning platforms said the students with full access to the study material as well as allow them to engage in online classes and interact with the teachers like the physical classroom setting. The feedback is encouraging from both teachers and students. Students are abiding by the learning schedule and

submitting their assignments on time. All this contributes to personalized learning of students. There are many other benefits associated with digital or virtual classes, especially promoting students' voice and choice, a flexible learning pace, and the ability to learn anytime, from anywhere. Adaptive learning is one of the techniques for providing personalized learning experiences, to enable effective and tailored learning paths to engage students and address their individual needs.

\section{Covid-19 outbreak triggering the new education revolution}

Ironically, it has taken a pandemic like Covid-19 outbreak to get the education sector to swing to digital mode with both human and technical support. The only reason that universities and some schools in districts have been able to march towards remote learning is that technology stack has evolved a good bit in the last four years. The utilization of technology has opened up new opportunities of learning for students of all ages and tossing the traditional notion of classrooms and education by breaking the geographical barrier. Technology has led a pedagogical change while addressing concerns that affect teaching, learning and social functionalities. Till the time this dreaded pandemic gets controlled, it is the digital learning that will bridge the gap between teachers and learners. Stay-at-home learning should continue

\section{Gratitude}

Finally, the seventh positive aspect that COVID-19 is giving us is a new sense of gratefulness. It has offered us a new perspective on everything we have taken for granted for so long - our freedoms, leisure, connections, work, family and friends. No one have imagined or questioned how life as we know it could be suddenly taken away from us. Fortunately, when this crisis is over, all nations will exhibit new levels of gratitude. The society have also learned to value and appreciate health workers effort, who are at the frontline of this crisis, risking their lives everyday by just 
showing up to their vital work. This sense of gratefulness can also help us develop our resilience and moral strength to overcome the crisis in the long- term. (psychologytoday.com, 2020), (berkeley.edu, 2020)

\section{Negative impacts of covid-19}

\section{Environment}

COVID 19's impact on the environment has been mixed. Although the pandemic resulted in improved environmental conditions, there have been other negative effects, some of which are obvious, others less so. In brief, the positive effects have been reduced GHG (greenhouse gas) emissions, improved water quality, reduced noise pollution, improved air quality and in some cases, wildlife restoration. Negative effects have been increased medical waste, haphazard disposal of PPE, increased municipal waste and reduced recycling efforts. (gage, The Coronavirus Pandemic's Impact on them Environment, 2020)

Masks: 129 billion are disposed globally each month Gloves :65 billion are disposed globally each month

The drastically increasing amount of domestic and medical waste is one of the key negative outcomes of COVID-19. Coronavirus waste became a new form of global pollution. The adopted quarantine, isolation, and social distancing led to a corresponding increase in the amount of solid household waste (15-25\%) and a significant increase in the generation of medical waste in healthcare institutions (from 10 to 20 times).

On waste management - [August 2020]; Media overview Coronavirus waste has become a new form of global pollution. The adopted quarantine, isolation, and social distancing led to a corresponding increase in the amount of solid household waste $(15-25 \%)$ and a significant increase in the generation of medical waste in healthcare institutions (from 10 to 20 times). To protect themselves from the viral infection, people are using face masks, hand gloves, and other safety equipment, which increases the amount of healthcare waste. Face masks are non-recyclable, they are contaminated with body fluids and could potentially lead to indirect infection and transmission of the virus if released into the recycling system.

From the beginning of 2020, a huge number of disinfectants has been applied to roads, commercial, and residential areas to exterminate the COVID-19 virus. These disinfectants can kill non-targeted beneficial species and create ecological imbalance. Much of the disinfectants and antiseptics, such as hand soap which contains a high percentage of the hormone-disrupting pesticide Triclosan (TSC -Triclosan converts to dioxin, a highly toxic compound when exposed to sunlight), is naturally finding its way into our water systems.

COVID-19's increased waste also affected waste management (WM) systems. Reduced employment / workers reduced recycling efforts which further 
compounded challenges in the collection and disposal of general waste. Municipal budgets were weakened as a result of increased healthcare costs, and implemented social security regulations. Several governments introduced limitations to the volume of recycling activities in order to reduce the risk of virus infection. (Survey on the impact of the COVID-19 on municipal waste management systems, [2020])

COVID-19 is the latest of several recent zoonotic diseases1 in humans and demonstrates how human health and nature are closely intertwined. Interaction with nature could expose humans to a range of animal diseases. In fact, about three to four new infectious diseases occur every year, most of which originate from wild animals. Over the past 30 years, approximately $60-70 \%$ of new human diseases have been of zoonotic origin. The growth of zoonotic disease outbreaks is a sign of a breakdown in the relationship between humans and nature and is likely to worsen.

\section{Education}

The global impact of Coronavirus is immense as educational institutes all over the world - from Harvard to the IITs - are closed. Covid-19 has thrown education all over the world in a loop. Here are the major problems. Schools are shut, and students are stranded at home, with extremely limited contact with friends and virtually no physical activity, thanks to the Covid-19 pandemic raging across the world. IB, A Levels, ICSE, CBSE all known and recognized boards have postponed or cancelled examinations. Likewise, top colleges like MIT, Harvard, Princeton have closed. Closer home, institutions like IITs and IIMs have all closed their campuses and moved classes online. Even standardized tests like GMAT, GRE, SATs, ACT remain suspended and the future of many students hangs in balance! Clearly, there is panic all around and educators and students alike are confused as to next steps and continuity with respect to educational objectives. In our opinion there are three major education problems that students and educators currently face due to the Covid-19 pandemic. (Indiatoday.in/education-today/featurephilia/story, 2020)

The world today is facing the biggest public health risk which is leading to one of the largest and the quickest reorganization of the world order. By the end of March 2020, the epidemic had spread to over 185 countries and resulted in the closure of over 90 percent of all schools, colleges and universities impacting close to 1.38 billion students. The speed of the spread of the epidemic, the closure of higher education institutions and the transition to online teaching was so swift that it hardly gave any time to plan and to reflect on the potential risks or the potential opportunities that such a sudden change could bring.

Given such a situation it is important to look at the impact and reflect on what has transpired and what is likely to happen as we move forward in the field of global education. 


\section{Four negative impacts of Covid-19 on education:}

There are a number of areas of potential risks for global education. Here are 4 negative impacts of Covid-19 on education:

\section{1. Sluggish cross-border movement of students}

Universities in many countries such as Australia, UK, New Zealand, and Canada are highly dependent on the movement of students from China and India. Many parents will avoid sending students abroad for higher education due to high risk from the pandemic.

\section{2. Passive learning by students}

The sudden shift to online learning without any planning -- especially in countries like India where the backbone for online learning was not ready and the curriculum was not designed for such a format -- has created the risk of most of our students becoming passive learners and they seem to be losing interest due to low levels of attention span.

Added to this is that we may be leaving a large proportion of the student population untouched due to the digital divide that is part of many developing nations including India.

We are now beginning to realize that online learning could be dull as it is creating a new set of passive learners which can pose new challenges.

\section{3. Unprepared teachers for online education}

Online learning is a special kind of methodology and not all teachers are good at it or at least not all of them were ready for this sudden transition from face-to-face learning to online learning. Thus, most of the teachers are just conducting lectures on video platforms such as Zoom which may not be real online learning in the absence of a dedicated online platform specifically designed for the purpose.

\section{4. Changing format of student recruitment}

Universities and colleges worldwide are facing a major risk in the area of student recruitment and retention. The risk of losing students is so high that they will need to re-look at their admission practices, admission criteria and the overall recruitment process itself which will include, new methods of outreach and application process itself. Many schools, colleges and universities switched to platforms from the likes of Microsoft and Google along with various conferencing apps such as skype, zoom, google meet, for conducting online classes. A shift in the teaching methodology is being observed at-large. A large number of private schools in urban cities made arrangements and trained teachers to teach communicate and engage with students in online classes. These e-learning programs have been designed to improve communication with each other. While learning through tutorials, video calls, sharing 
screens and enabling learning software, help students make the most of their virtual learning experience.

\section{Underprivileged students are lagging behind in the age of digital learning.}

However, a large section of students from underprivileged/ backward families or living in remote areas don't have access to the internet. Moreover, a considerable fragment of teachers and students are not equipped to configure the online class model to teach. So, we really have to look at democratizing education. At the end of the day, students, irrespective where they are and how old they are, learning should never stop. As an immediate response to the medical crisis, adaptability towards digital learning has been accelerated.

\section{Classroom environment is best for learning.}

However, a physical classroom environment and interaction has been perceived as the best form of teaching-learning method. Though globally, online education has witnessed some success, in India and most third world countries, digital learning would still take time before it is seen as a mainstream learning style. However, the Covid-19 outbreak, and the resultant lockdown, has forced the adoption of digital education amongst the learners. The hope is, it might as well lead to newer teachinglearning patterns that could prove to be more effective and efficient in the long run.

\section{Other negative impacts on education}

As the world becomes increasingly interconnected, so do the risks we face. The COVID-19 pandemic has not stopped at national borders. It has affected people regardless of nationality, level of education, income or gender. But the same has not been true for its consequences, which have hit the most vulnerable hardest. Education is no exception. Students from privileged backgrounds, supported by their parents and eager and able to learn, could find their way past closed school doors to alternative learning opportunities. Those from disadvantaged backgrounds often remained shut out when their schools shut down. This crisis has exposed the many inadequacies and inequities in our education systems - from access to the broadband a computer needed for online education, and the supportive environments needed to focus on learning, up to the misalignment between resources and needs.

The lockdowns in response to COVID-19 have interrupted conventional schooling with nationwide school closures in most OECD and partner countries, the majority lasting at least 10 weeks. While the educational community have made concerted efforts to maintain learning continuity during this period, children and students have had to rely more on their own resources to continue learning remotely through the Internet, television or radio. Teachers also had to adapt to new pedagogical concepts and modes of delivery of teaching, for which they may not have been trained. In particular, learners in the most marginalised groups, who don't have access to digital learning resources or lack the resilience and engagement to learn on their own, are at risk of falling behind. 
Hanushek and Woessman have used historical growth regressions to estimate the long-run economic impact of this loss of the equivalent to one-third of a year of schooling for the current student cohort. Because learning loss will lead to skill loss, and the skills people have related to their productivity, gross domestic product (GDP) could be $1.5 \%$ lower on average for the remainder of the century. The present value of the total cost would amount to $69 \%$ of current GDP for the typical country. (EA Hanushek L. W., 2008), (EA Hanushek L. W., 2007), (EA Hanushek L. W., 2007).

These estimates assume that only the cohort currently in school are affected by the closures and that all subsequent cohorts resume normal schooling. If schools are slow to return to prior levels of performance, the growth losses will be proportionately higher. Of course, slower growth from the loss of skills in today's students will only be seen in the long term. However, when considered over this term, the impact becomes significant. In other words, countries will continue to face reduced economic well-being, even if their schools immediately return to pre-pandemic levels of performance. For example, for the United States, if the student cohorts in school during the 2020 closures record a corona-induced loss of skills of one-tenth of a standard deviation and if all cohorts, thereafter return to previous levels, the $1.5 \%$ loss of future GDP would be equivalent to a total economic loss of USD 15.3 trillion. (Woessmann L. (2007), (Hanushek Eric A., Ludger W. 2007)

The COVID-19 pandemic has also had a severe impact on higher education as universities closed their premises and countries shut their borders in response to lockdown measures. Although higher education institutions were quick to replace face-to-face lectures with online learning, these closures affected learning and examinations as well as the safety and legal status of international students in their host country. Perhaps most importantly, the crisis raises questions about the value offered by a university education which includes networking and social opportunities as well as educational content. To remain relevant, universities will need to reinvent their learning environments so that digitalisation expands and complements studentteacher and other relationships. Reopening schools and universities will bring unquestionable benefits to students and the wider economy. In addition, reopening schools will bring economic benefits to families by enabling some parents to return to work. Those benefits, however, must be carefully weighed against the health risks and the requirement to mitigate the toll of the pandemic. The need for such trade-offs calls for sustained and effective coordination between education and public health authorities at different levels of government, enhanced by local participation and autonomy, tailoring responses to the local context. Several steps can be taken to manage the risks and trade-offs, including physical distancing measures, establishing hygiene protocols, revising personnel and attendance policies, and investing in staff training on appropriate measures to cope with the virus. 


\section{Peace}

The COVID-19 pandemic has impacted politics, both international and domestic, by affecting the governing \& political systems of multiple countries, causing suspensions of legislative activities, isolation or deaths of multiple politicians and rescheduling of elections due to fears of spreading the virus. The pandemic has triggered broader debates about political issues such as the relative advantages of democracy and autocracy, how states respond to crises, politicization of beliefs about the virus, and the adequacy of existing frameworks of international cooperation. Additionally, the pandemic has, in some cases, posed several challenges to democracy, leading to it being fatally undermined and damaged. (Ang, Yuen Yuen (2020), (Stasavage, David (2020), (Lipscy, Phillip (2020),( Druckman, James; Klar, Samara,2020), (Fazal, Tanisha $(2020$

The coronavirus pandemic appears to have worsened conflict dynamics: it has also led to a United Nations Security Council resolution demanding a global ceasefire. On March 23, 2020, United Nations Secretary-General António Guterres issued an appeal for a global ceasefire as part of the United Nations' response to the COVID-19 coronavirus pandemic. On 24 June 2020, 170 UN Member States and Observers signed a non-binding statement in support of the appeal, rising to 172 on 25 June 2020. On 1 July 2020, the UN Security Council passed resolution S/RES/2532 (2020), demanding a "a general and immediate cessation of hostilities in all situations on its agenda," expressing support for "the efforts undertaken by the Secretary-General and his Special Representatives and Special Envoys in that respect," calling for "all parties to armed conflicts to engage immediately in a durable humanitarian pause" of at least 90 consecutive days, and calling for greater international cooperation to address the pandemic. (Mustasilta, Katariina (2020),(United Nations Secretary-General. 23 March 2020) ( United Nations News. 23 March 2020),(UN News. 24 June 2020).

\section{Connectedness}

During periods of turmoil such as the Covid-19 pandemic, firms with more resilient business models tend to survive and expand more than others. While global production and export networks expose firms to foreign pandemic shocks, they potentially make firms less susceptible to domestic pandemic shocks through diversification of suppliers and markets. In addition, higher market power could provide buffers by allowing bigger margins of adjustment. The recent COVID-19 pandemic has influenced our society in various ways. In particular, changes in business environments induced by border closures, lockdown policies, social distancing, and preference changes have generated a spike in uncertainty, significant disruptions in business, and a reallocation across firms. (Baker S R, Bloom N, Davis $S$ J and Terry S J (2020), (Barrero, J M, N Bloom and S J Davis (2020), ( Ding, Levine W R, Lin C and Xie W (2020).

During periods of such turmoil, firms with more resilient business models tend to survive and expand more than others, which leads to an important question of what 
characteristics of firms are vital in managing crises. The recent publication attempts to answer this question with particular emphasis on two firm characteristics - global connectedness and market power - which play central roles in the economics and finance literature, and have attracted a great deal of attention in the last decade. (Hyun J, Kim D and S- Shin R (2020).

\section{Global integration: Necessarily bad during the pandemic?}

The global economy has so far evolved toward integration through global value chains, trade, and migration, and there is now a consensus in the media and policy circles that global integration has exacerbated the negative impact of the pandemic crisis, both through the direct spread of the disease and through the disruption in foreign supply and demand. From a theoretical point of view, however, more globally connected firms via supply chains and exports could enjoy a more diversified portfolio of suppliers and markets, which would potentially allow them to buffer negative domestic shocks by making more flexible decisions in production and market management. Another firm characteristic, market power (which we measure through mark-up), could also make firms more resilient to negative shocks by providing bigger margins of adjustment and flexibility, as a large degree of mark-up implies that the firms' products are not easily substituted for others, allowing the firms to adjust prices without a significant decline in demand.

(Baker S R, Bloom N, Davis S J and Terry S J (2020).

Descriptive evidence: Firms with higher global connectedness and market power performed better in stock markets

Using a weekly global stock market dataset of covering 8,000 listed firms in 71 countries for the first five months of 2020, we investigate how pre-pandemic firm characteristics, including global connectedness and market power, affect firms' stock market performances in response to the COVID-19 pandemic shock. We primarily focus on a firm's market value, which equates to the present value of the expected future stream of profits (or dividends). (Barrero J M, Bloom N and Davis S J (2020)).

Thus, changes in stock market value reflect investors' information about firms' current and future performances, shows the evolution of the average market value of the US firms as a function of their degree of global connectedness (measured by foreign supplier share and export share) and market power (measured by mark-ups). Specifically, we group firms separately across those in the top and bottom quantiles of scores, foreign supplier share, and export share distributions. Firms with higher profits and who are more globally integrated through supply chains and exports, differentially performed better compared to those with lower mark-ups and who are less globally integrated. This descriptive exercise suggests that global production and export networks as well as profits potentially allow firms to be more resilient during crisis periods. (Bonadio

B, Huo Z, Levchenko A A and Pandalai-Nayar N (2020). 
Regression Analysis: Global connectedness and market power make firms more resilient to the domestic pandemic shock

The result confirms carried out using a formal regression analysis. Specifically, the regress of firm's weekly market value growth on various explanatory variables, including the domestic pandemic shock measured by weekly growth rate in domestic total confirmed cases and its interaction with various pre- pandemic firm characteristics, including measures of global connectedness through global supply chains and exports, mark-ups as a measure of market power, employment, and various financial conditions. Also control for measures of foreign pandemic shocks, any time-varying and time-invariant industry and/or country differences that might influence stock market reactions to the pandemic, as well as time-invariant unobserved firm characteristics. (Ding W, Levine R, Lin C and Xie W, 2020).

First, consistent with widely accepted views, global supply chain and exports negatively affect firms' market value by transmitting foreign pandemic shocks. However, we find a significant heterogeneous response to the domestic pandemic shock: firms with larger foreign supplier share, export share, and mark up experience smaller decrease of weekly market value growth in reacting to the domestic pandemic shock. This result is consistent with the view that global connectedness and market power make firms more resilient to domestic shocks by diversifying the markets and suppliers and by providing more flexibility and margins of adjustment in response to negative shocks. (Gormsen N J and Koijen R S J ,2020).

\section{Innovation}

Countries that implement similar (Centres for Disease Control) CDC-style recommendations in relation to COVID-19 may experience less dislocation, although there may still be an economic impact. School closures and social distancing might reduce the available labour force in an area experiencing a pandemic, for example. We might then observe mild rolling economic impacts as outbreaks occur in various regions. A severe public reaction in which local authorities or people themselves decide on extremely strict measures in a given area could create significant economic costs, particularly in regions and for industries that specialize in production that can't be done virtually (such as manufacturing). If many countries opt for this type of response, the impact on the global economy could be quite large.

Economic centres around the world are subject to Wuhan-style shutdowns as people panic over the spread of the virus. Uncoordinated decisions on a country-by-country basis disrupt the movement of both people and goods. Global manufacturing declines, as businesses with international supply chains can operate only intermittently. Tourism and related businesses decline sharply, and tourism-based businesses and regions suffer. It takes more than a year for the World Health Organization and the United Nations to develop an accepted global response that prioritizes health measures based on effectiveness and cost to the wider economy, and for this response 
to be accepted in the major world economies. Global GDP stagnates, international trade falls, and a global recession is a distinct possibility.

Delayed shipments and production schedules create financial problems for companies with heavy debts, especially in the United States. The decline in global equity markets and flight from risk-investors selling assets such as high-yield bonds and volatile stocks-exposes investors who have under-priced risk. Concern about counterparty risk accelerates the decline and dries up liquidity in financial markets. Central banks scramble to manage the problem. Financial markets-and the global economy-recover after a $\mathrm{V}$ - shaped recession. The coronavirus recession is an economic recession happening across the world economy in 2020 due to the COVID19 pandemic. (https://www2.deloitte.com/2020), (Schwartz, Nelson D. (21 March 2020),( Horowitz, Julia , March 2020),( Lowrey, Annie (9 March 2020).

Global stock markets experienced their worst crash since 1987, and in the first three months of 2020 the G20 economies fell 3.4\% year-on-year. Between April and June 2020, the International Labour Organization estimated that an equivalent of 400 million full-time jobs were lost across the world, and income earned by workers globally fell 10 percent in the first nine months of 2020, equivalent to a loss of over US\$3.5 trillion. (Jenkins, Simon (9 March 2020)), (OECD. 11 June 2020)), (McKeever, Vicky (30 June 2020)).

\section{Conclusion and Summary}

At the end of 2019, a novel coronavirus, designated as SARS-CoV-2, (Severe Acute Respiratory Syndrome-CoV-2). emerged in Wuhan, China and was identified as the causal pathogen of COVID-19. The epidemic scale of COVID-19 has increased dramatically, with confirmed cases increasing across China and globally. Understanding the potential affecting factors involved in COVID-19 transmission will be of great significance in containing the spread of the pandemic. Environmental and meteorological factors might impact the occurrence of COVID-19, as these have been linked to various diseases, including SARS

A series of strict lockdown measures were implemented in the areas of China worst affected by coronavirus 19 disease, including Wuhan, to prevent the disease spreading this was implemented globally all over the world as the pandemic speedily spread. The lockdown had a substantial environmental impact, because traffic pollution and industrial emissions are important factors affecting air quality and public health in the region. Restrictive measures in different regions according to the level of the epidemic spread.

These measures included reducing public transportation and closing schools and business centres. These quarantine measures effectively alleviated the spread of the COVID-19 epidemic.

Global impact of covid-19 on education was very immense. The speed of the spread of the pandemic, the closure of schools, colleges, higher education institutions and the 
transition to online teaching was so quick that there was no time to plan and to reflect on the potential risks or the potential opportunities that such a sudden shutdown could bring. Given such a situation it is important to look at the impact and reflect on what has transpired and what is likely to happen as we move forward in the field of global education.

The world of work is being profoundly affected by the global virus pandemic. In addition to the threat to public health, the economic and social disruption threatens the long-term livelihoods and wellbeing of millions. The coronavirus disease continues to spread across the world following a trajectory that is difficult to predict. The health, humanitarian and socio-economic policies adopted by countries will determine the speed and strength of the recovery.

The spread of COVID-19 has sent shockwaves across the globe. The public health crisis, unprecedented in our lifetimes, has caused severe human suffering and loss of life. The exponential rise in infected patients and the dramatic consequences of serious cases of the disease have overwhelmed hospitals and health professionals and put significant strain on the health sector. As governments grappled with the spread of the disease by closing down entire economic sectors and imposing widespread restrictions on mobility, the sanitary crisis evolved into a major economic crisis which is expected to burden societies for years to come. According to the OECD's [Organisation for Economic Co-operation and Development] latest Economic Outlook, even the most optimistic scenarios predict a brutal recession.

Even if a second wave of infections is avoided, global economic activity is expected to fall by $6 \%$ in 2020 , with average unemployment in OECD countries climbing to $9.2 \%$, from $5.4 \%$ in 2019. In the event of a second large-scale outbreak triggering a return to lockdown, the situation would be worse. (OECD, 2020). (WHO int/news2020)

The outlook is very uncertain. But, if anything, the pandemic has exposed our vulnerability to crises and revealed how precarious and interdependent the economies we have built can be. Disruptions on the scale we have just witnessed are not limited to pandemics, but may also result from natural, political, economic and environmental disorder. Our capacity to react effectively and efficiently in the future will hinge on governments' foresight, readiness and preparedness. Through their role in developing the competencies and skills needed for tomorrow's society, education systems will need to be at the heart of this planning. This includes rethinking how the economy should evolve to guard against adversity, and defining the skills, education and training required to support it. This also means working in close collaboration with other government sectors and the private sector to increase the attractiveness and labour-market prospects of certain professions, including those considered paramount for the common good. Real change often takes place in deep crises, and this moment holds the possibility that we won't return to the status quo when things return to "normal". While this crisis has deeply disruptive implications, including for education, it does not have predetermined outcomes. It will be the nature of our 
collective and systemic responses to these disruptions that will determine how we are affected by them. In this sense, the pandemic is also a call to renew the commitment to the Sustainable Development Goals. Ensuring that all young people have the opportunity to succeed at school and develop the knowledge, skills, attitudes and values that will allow them to contribute to society is at the heart of the global agenda and education's promise to our future society.

Whether we close our boarder we cannot help but joined our forces together or we might be overtaken by the scourge of this new vicious murderous viral disease. We may close our boarder but we cannot close it from the airborne viral disease. Only time can tell whether the strategies being employed by most countries is indeed effective. It is a treacherous disease; you may seem to fully get well but it could return with more serious complication out of nowhere.

We become introspective and concern not only for ourselves but for everyone. Because we need to eradicate the disease not human beings. This disease does not respect you race or economic standing.

The current crisis has tested our ability to deal with large-scale disruptions. It is now up to us to build as its legacy a more resilient society.

\section{How COVID-19 affected the future of work}

The short and long-term disruptions to work and employment sectors from COVID19 vary. During the pandemic, the virus most severely disturbed the work sectors with the highest physical proximity score: medical care, on-site customer service, personal care, and leisure and travel. The leisure and travel sector including restaurants, airports, and entertainment venues were hugely impacted on. Workers in these fields require daily interaction with crowds of new people. COVID-19 forced most of these venues to close in 2020 and airports and airlines were operating in severely limited capacity. In the longer term, reduction in business travel due to the shift to remote work and the automation of some occupations, such as food service roles, may impose a restriction on labour demand in this arena and therefore a rise in unemployment levels. Remote work may also put a dent in business travel as the extensive use of videoconferencing during the pandemic has ushered in a new acceptance of virtual meetings in most aspects of work. While leisure travel and tourism are likely to rebound after the crisis, McKinsey's travel practice estimates that about 20 percent of business travel, the most lucrative segment for airlines, may not recover. This would have significant knock-on effects on employment in commercial aerospace, airports, hospitality, and food service.

The computer-based office work sector, including offices and administrative roles in hospitals, courts, and factories, require only moderate number of human interactions and therefore nearly all of these roles became remote and there are potential talks that these may remain remote roles due to the benefits of cut in costs for building and maintenance fees for employers. 
COVID-19 had little impact on the outdoor production and maintenance sector such as construction sites, farms, residential and commercial grounds, and other outdoor based work roles due to the low physical proximity with other people and the fact that the roles take place fully outdoors where essentially there is natural ventilation and lower risk of virus transmission.

Many consumers discovered the convenience of e-commerce and other online activities during the pandemic. In 2020, the share of e-commerce grew at two to five times the rate before COVID-19. Roughly three-quarters of people using digital channels for the first time during the pandemic say they will continue using them when things return to "normal" according to McKinsey Consumer Pulse surveys conducted around the world. This shift to digital transactions has propelled growth in delivery, transportation, and warehouse jobs. In China, e-commerce, delivery, and social media jobs grew by more than 5.1 million during the first half of 2020. COVID19 may propel faster adoption of automation and AI (artificial intelligence), especially in work sectors with high physical proximity. Many companies deployed automation and $\mathrm{AI}$ in warehouses, grocery stores, call centres, and manufacturing plants to reduce workplace density and cope with surges in demand. (Susan Lund, 2020)

\section{Discussion}

It is important that we realise the long-term impact of Covid-19, and not just the immediate effects.

Responsible organisations such as the WHO [World Health Organisation], and other scientific and medical commissions should guide and support the work carried out by scientists, and medics in tackling the most challenging aspects of the pandemic's legacy in building a better future for countries around the world. The positive and negative impact of Covid-19 on the environment has been mixed. Although the pandemic has caused an improvement in environmental conditions, there are also negative effects, some are known and others less obvious. Briefly the positive impact was the reduction in GHG (greenhouse gas) emissions, which improved the quality of environmental conditions, such as improved air quality, reduced noise pollution and wild life restoration. Negative effects included increased medical waste, hazard disposal of PPE (personal protection Equipment), increased municipal waste and reduced recycling process. The world has agreed on an international inquiry into the origins of the virus, handling and response of the pandemic, however the outcome of this is likely to be many years away. Advances in medicine have kept many epidemics manageable, many speculated that it was only a matter of time before a global pandemic of this magnitude was to take place. There have been so many more direct and indirect effects of the COVID-19 pandemic, of which will be understood in the months and even years to come, but what is evident in the short-term, is that all of us should urgently stand up and work out how we can play our part in protecting and rehabilitating the world's biodiversity which is currently balancing on a very delicate thread. 


\section{References}

[1] https://www.ifac.org/system/files/publications/files/IAASB-Staff-Alert-GoingConcern-April-2020.pdf

[2] https://lighthouse.mq.edu.au/.../seven-positive-outcomes-of-covid-19

[3] (how-is-the-covid-19-pandemic-affecting-education-all-over-the-world, 202004-07)

[4] https://www.bbc.com/future/article/20200326-covid-19-the-impact-ofcoronavirus-on-the-environment.

[5] https://www.un.org/en/un-coronavirus-communications-team/fury-virusillustrates-folly-war

[6] "Pandemic knocks a tenth off incomes of workers around the world". Financial Times. 23 September 2020. Retrieved 23 September 2020.

[7] https://www.newyorker.com/culture/video-dept/the-italians-making-musicon-balconies-under- coronavirus-quarantine

[8] https://www.jnj.com/caring-and-giving/how-johnson-johnson-is-helpingsupport-coronavirus-relief- efforts

[9] https://www.woolworths.com.au/shop/discover/community/news/woolworth s-to-introduce-a-dedicated-shopping-hour-for-the-elderly-and-people-withdisability

[10] https://www.optus.com.au/for-you/support/answer?id=20065

[11] R205 - Employment and Decent Work for Peace and Resilience Recommendation, 2017 (No. 205)

[12] https://www.newyorker.com/news/our-local-correspondents/the-great-zoomschool-experiment.

[13] https://www.timeshighereducation.com/opinion/could-coronavirus-forcepositive-change-higher- education.

[14] https://www.indiatoday.in/education-today.

[15] Kamlesh Misra, Vice-Chancellor, Rishi hood University (PhD North-eastern University, Boston)

[16] https://www.indiatoday.in/education-today/featurephilia/story/covid-19education-system-classroom-e- learning-coronavirus-outbreak-1667970-202004-17.

[17] https://www.psychologytoday.com/us/blog/journey-healing/202003/gratefulin-the-time-coronavirus.

[18] https://greatergood.berkeley.edu/topic/gratitude.

[19] Meuresiduo website; Green Matters website; Venn gage - The Coronavirus Pandemic's Impact on them Environment - [April 2020]; National Centre for Biotechnology Information - Impact of COVID-19 pandemic 
[20] IFC - COVID-19's Impact on the Waste Sector - [2020]; Association of cities and regions for sustainable resource management - Survey on the impact of the COVID-19 on municipal waste management systems - [2020]; National Centre for Biotechnology Information - Environmental effects of COVID-19 pandemic and potential strategies of sustainability - [2020]

[21] https://www.indiatoday.in/education-today/featurephilia/story/how-is-thecovid-19-pandemic-affecting- education-all-over-the-world-1664380-2020-0407.

[22] The role of cognitive skills in economic development, EA Hanushek, L Woessmann - Journal of economic literature, 2008

[23] The role of education quality for economic growth*, EA Hanushek, L Wößmann $-2007$

[24] The role of school improvement in economic development*, EA Hanushek, L Wößmann - 2007

[25] Woessmann (2007). “*, E Hanushek - Education Quality and Economic Growth." Washington, 2003.

[26] The Role of School Improvement in Economic Development*A Hanushek Eric, W Ludger - 2007.

[27] Ang, Yuen (2020). "When COVID-19 meets centralized, personalized power". Nature Human Behaviour. 4 (5): 445-447. doi:10.1038/s41562-020-0872-3. PMID 32273583. S2CID 215532797.

[28] Stasavage, David (2020). "Democracy, Autocracy, and Emergency Threats: Lessons for COVID-19 From the Last Thousand Years". International Organization. 74: E1-.doi:10.1017/S0020818320000338.

[29] Lipscy, Phillip (2020). "COVID-19 and the Politics of Crisis". International Organization. 74: E98- E127. doi:10.1017/S0020818320000375. S2CID 225135699.

[30] Druckman, James; Klar, Samara (2020). "How Affective Polarization Shapes Americans' Political Beliefs: A Study of Response to the COVID-19 Pandemic". Journal of Experimental Political Science: 1-12. doi:10.1017/XPS.2020.28. S2CID 222312130.

[31] Fazal, Tanisha (2020). "Health Diplomacy in Pandemical Times". International Organization. 74: E78- E97. doi:10.1017/S0020818320000326. S2CID 229265358.

[32] Mustasilta, Katariina (2020). "FROM BAD TO WORSE? The impact(s) of Covid19 on conflict dynamics". Conflict Series. European Union Institute for Security Studies (EUISS). Retrieved 1 August 2020.

[33] "Transcript of the Secretary-General's virtual press encounter on the appeal for global ceasefire". United Nations Secretary-General. 23 March 2020. Retrieved 1 August 2020. 
[34] ^ "170 signatories endorse UN ceasefire appeal during COVID crisis".. Retrieved 1 August 2020.

[35] Baker, S R, N Bloom, S J Davis and S J Terry (2020), "COVID-Induced Economic Uncertainty", NBER Working Paper 26983.

[36] Barrero, J M, N Bloom and S J Davis (2020), “COVID-19 Is Also a Reallocation Shock", NBER Working Paper 27137.

[37] Ding, W, R Levine, C Lin and W Xie (2020), "Corporate Immunity to the COVID19 Pandemic", NBER Working Paper 27055

[38] Hyun, J, D Kim and S-R Shin (2020), "The Role of Global Connectedness and Market Power in Crises: Firm-level Evidence from the COVID-19 Pandemic", Covid Economics: Vetted and Real-Time Papers.

[39] Baker, S R, N Bloom, S J Davis and S J Terry (2020), "COVID-Induced Economic Uncertainty", NBER Working Paper 26983.

[40] Barrero, J M, N Bloom and S J Davis (2020), "COVID-19 Is Also a Reallocation Shock", NBER Working Paper 27137.

[41] Bonadio, B, Z Huo, A Levchenko and N Pandalai-Nayar (2020), "The role of global supply chains in the COVID-19 pandemic and beyond", VoxEU.org, 25 May.

[42] Ding, W, R Levine, C Lin and W Xie (2020), "Corporate Immunity to the COVID19 Pandemic", NBER Working Paper 27055.

[43] Gormsen, N J and R S J Koijen (2020), "Coronavirus: Impact on Stock Prices and Growth Expectations", VoxEU.org, 23 March.

[44] https://www2.deloitte.com/.../covid-19/economic-impact-covid-19.html.

[45] Horowitz, Julia. "A 'short, sharp' global recession is starting to look inevitable". CNN.com. Archived from the original on 20 March 2020. Retrieved 26 March 2020.

[46] "Pandemic knocks a tenth off incomes of workers around the world". Financial Times. 23 September 2020. Retrieved 23 September 2020.

[47] Susan Lund, (2020), https://www.mckinsey.com/featured-insights/future-ofwork/the-future-of-work- after-covid-19./2020. 
[48] "G20 GDP Growth - First quarter of 2020, OECD". OECD. 11 June 2020. Retrieved 6 September 2020.

[49] Lowrey, Annie (9 March 2020). "The Coronavirus Recession Will Be Unusually Difficult to Fight". The Atlantic. Archived from the original on 24 March 2020. Retrieved 24 March 2020.

[50] Jenkins, Simon (9 March 2020). "There will be no easy cure for a recession triggered by the coronavirus". Archived from the original on 24 March 2020. Retrieved 24 March 2020 - via www.theguardian.com.

[51] https://www.edsurge.com/news/2020-03-18-as-coronavirus-closes-collegesthe-campus-tour-goes- virtual.

[52] Schwartz, Nelson D. (21 March 2020). "Coronavirus Recession Looms, Its Course 'Unrecognizable'". The New York Times. Archived from the original on 24 March 2020. Retrieved 24 March2020.

[53] A b Palumbo, Daniele (28 March 2020). "Coronavirus: A visual guide to the economic impact". BBC News. Archived from the original on 27 March 2020.

[54] Por Redacción de TVN Noticias (30 March 2020). "PNUD: 'La pandemia dejará cicatrices muy profundas en el planeta'". Tvn-2.com. Retrieved 3 April 2020.

[55] https://lighthouse.mq.edu.au/article/april-2020/coronavirus-sees-companiesdeliver-for-the-greater-good

[56] "Earth Observatory". Archived from the original on 2 April 2020. Retrieved 9 April 2020.

[57] https://www.abc.net.au/news/2020-04-10/saudi-led-ceasefire-in-yemenamid-coronavirus-hopes-for- peace/ 12140410

[58] UN News. 24 June 2020"COVID-19: UN chief calls for global ceasefire to focus on 'the true fight of our lives'". UN News. 23 March 2020. Retrieved 1 August2020.

[59] McKeever, Vicky (30 June 2020). "The coronavirus is expected to have cost 400 million jobs in the second quarter, UN labor agency estimates". CNBC. Retrieved 6 September 2020.

[60] https://www.who.int/news/item/13-10-2020-impact-of-covid-19-on-people... [61] https://www.msn.com/en-in/news/world/covid-19-4-negative-impacts-and-4opportunities-created-for- education/ar-BB13YhKZ. 